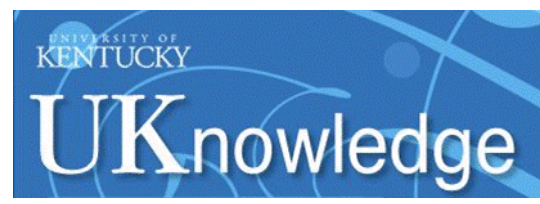

University of Kentucky

UKnowledge

\title{
Targeting Intensive Job Assistance to Ex-Offenders by the Nature of Offense: Results from a Randomized Control Trial
}

Christopher R. Bollinger

University of Kentucky, crboll@email.uky.edu

Aaron Yelowitz

University of Kentucky, aaron.yelowitz@uky.edu

Follow this and additional works at: https://uknowledge.uky.edu/isfe_papers

Part of the Economics Commons

Right click to open a feedback form in a new tab to let us know how this document benefits you.

\section{Repository Citation}

Bollinger, Christopher R. and Yelowitz, Aaron, "Targeting Intensive Job Assistance to Ex-Offenders by the Nature of Offense: Results from a Randomized Control Trial" (2021). Institute for the Study of Free Enterprise Working Papers. 37.

https://uknowledge.uky.edu/isfe_papers/37

This Research Paper is brought to you for free and open access by the Institute for the Study of Free Enterprise at UKnowledge. It has been accepted for inclusion in Institute for the Study of Free Enterprise Working Papers by an authorized administrator of UKnowledge. For more information, please contact UKnowledge@lsv.uky.edu. 


\title{
Targeting Intensive Job Assistance to Ex- Offenders by the Nature of Offense: Results from a Randomized Control Trial
}

\section{Christopher R. Bollinger Aaron Yelowitz}

January 2021

Institute for the Study of Free Enterprise

Working Paper 38

\author{
University of Kentucky \\ 244 Gatton College of Business and Economics \\ Lexington, KY 40506-0034 \\ http://isfe.uky.edu/
}

\section{舀 Gatton College of




\title{
Targeting Intensive Job Assistance to Ex-Offenders by the Nature of Offense: Results from a Randomized Control Trial
}

\author{
Christopher R. Bollinger \\ Department of Economics \\ University of Kentucky \\ Aaron Yelowitz ${ }^{1}$ \\ Department of Economics \\ University of Kentucky and IZA
}

January 2021

\begin{abstract}
As many as two-thirds of newly-released inmates will be arrested for a new offense within three years. This study evaluates the impact of job assistance on recidivism rates among ex-offenders. The job assistance program, run though the private company America Works, uses a network of employers to place clients. Ex-offenders were randomly assigned to intensive job assistance (treatment group) or the standard program (control group). The intensive program is meant to improve average work readiness for ex-offenders. It reduces the likelihood of subsequent arrest among non-violent ex-offenders, but has little effect on violent ex-offenders. The re-arrest rate for non-violent ex-offenders in the treatment group was 19 percentage points lower than those in the control group. The re-arrest rate for violent ex-offenders in the treatment group was indistinguishable from those in the control group. We estimate benefits from intensive job assistance from averted crimes and find that they outweigh the \$5,000 up-front cost for nonviolent ex-offenders.
\end{abstract}

We thank Jamie Sharpe, Lewis Warren, and Diana David for research assistance; and the Manhattan Institute for Policy Research for financial support. Howard Husock has provided many insights along the way. In addition, two anonymous referees gave excellent feedback.

\footnotetext{
${ }^{1}$ Corresponding Author: Department of Economics, Gatton College of Business and Economics, University of Kentucky, 550 South Limestone Street, Lexington, KY 40506. Telephone: (859) 257-7634. E-mail: aaron@uky.edu.
} 


\section{Introduction}

Approximately 650,000 people are released from federal and state jails and prisons in the U.S. annually. ${ }^{2}$ Ex-offenders face daunting challenges in returning to society. Upon release, they are likely to struggle with substance abuse, lack of adequate education and job skills, limited housing options, and mental health issues. ${ }^{3}$

A great deal of taxpayer money has been spent on job assistance programs for this group. The U.S. has a long history of providing federal funding for community employment programs for ex-offenders, generally involving some combination of job-readiness (résumé writing, interview techniques, and the like), job-training (teaching skills related to specific jobs), and jobplacement services (Visher et al. 2005). Although the direct benefits that come from such programs accrue to ex-offenders and are therefore private in nature, such programs also create social returns by lowering an individual's likelihood of recidivism (Drake et al. 2009; Bushway and Apel 2012; Cook et al, 2015). Having a legitimate job reduces the likelihood of recidivism for ex-offenders (Sampson and Laub 1997; Harer 1994).

Recidivism rates are extremely high; roughly two-thirds of ex-offenders are arrested for a new offense within three years of their release (Beck and Shipley 1989; Langan and Levin 2002). ${ }^{4}$ As noted in Cook et al. (2015), this is particularly true of violent offenders who face more difficult job placement experiences. Violent offenders in particular may be of significant concern to employers due to the perception that these individuals are more likely to be violent in general, potentially causing problems with other employees, customers and liability. If jobassistance programs reduce subsequent criminal activity as well as the chance that ex-offenders will be rearrested, then the social returns will be large. In the U.S., more than 23 million criminal offenses were committed in 2007, resulting in approximately $\$ 15$ billion in economic losses to victims and $\$ 179$ billion in government expenditures on police, judicial, and legal activities, as

\footnotetext{
${ }^{2}$ See http://www.justice.gov/archive/fbci/progmenu_reentry.html (accessed July 12, 2019). Holzer et al. (2003) note that more than 600,000 offenders are released, while Raphael (2010) notes that 725,000 inmates were released from either state or federal facilities. In 2011, more than 688,000 were released (Carson and Sabol, 2012).

${ }^{3}$ See http://www.nij.gov/topics/corrections/reentry/Pages/welcome.aspx (accessed July 12, 2019).

${ }^{4}$ This statistic comes from a Bureau of Justice Statistics (BJS) study on recidivism from prisoners released in 1994 from 15 states. A different research report found that the three-year recidivism rate was 45 percent for inmates released in 1999 and 43 percent for those freed in 2004 (Pew Center on the States 2011). A newer study on the recidivism rates of state prisoners released in 2005 revealed 68 percent were arrested within three years. See https://www.bjs.gov/index.cfm?ty=pbdetail\&iid=6266 (accessed July 12, 2019).
} 
well as corrections (U.S. Department of Justice 2004, 2007, 2008). As McCollister et al. (2010) show, even relatively small crimes - like vandalism and larceny/theft - entail social costs of several thousand dollars, while major crimes - rape/sexual assault and murder - impose extremely high costs on society.

With respect to finding employment, ex-offenders face many challenges because of supply-side factors as well as demand-side factors. ${ }^{5}$ One important supply-side factor is the low level of education, training, and job experience possessed by many ex-offenders. Researchers have found that 40-70 percent of ex-offenders are high school dropouts (Harlow 2003; Travis et al. 2001; Freeman 1992). Harlow (2003) also found that 21-38 percent were unemployed when initially incarcerated. Ex-offenders also face important demand-side barriers; most employers are very reluctant to hire individuals with criminal records (Holzer et al. 2003). Some jobs or occupations are legally closed to those with felony convictions (Hahn 1991), while other jobs require significant levels of trustworthiness that ex-offenders are unlikely to have (Holzer et al. 2003). Many companies are also averse to employing ex-offenders because of the legal risk from negligent hiring (Glynn 1988; Bushway 1996; Connerley et al. 2001).

Widespread use of criminal background checks increases the difficulty for ex-offenders to find employment. The National Task Force on the Commercial Sale of Criminal Justice Information notes an "explosion" in criminal background checks since September 11, 2001, with millions of additional criminal record checks routinely conducted. ${ }^{6}$ Approximately two-thirds of employers conduct criminal background checks on all job candidates (Society for Human Resource Management 2012). Roughly half conduct such checks to reduce liability for negligent hiring and to ensure a safe work environment. Non-violent felonies, in addition to violent crimes, are very influential in decisions not to extend job offers. Recent experimental work finds that employers that asked about criminal records were $63 \%$ more likely to call applicants with no criminal record (Agan and Starr, 2018). Interestingly, callback rates do not vary much by nonviolent crime type or race (Agan and Starr, 2017). Public sentiment towards background checks has waned in recent years coinciding with government-imposed "ban the box" policies, which

\footnotetext{
${ }^{5}$ Holzer et al. (2003) note that supply-side factors include limited education, cognitive skills, and work experience as well as substance abuse and other physical/mental health problems. Many ex-offenders also face racial discrimination.

${ }^{6} \mathrm{See}$ http://www.search.org/files/pdf/ReportofNTFCBA.pdf (accessed July 12, 2019) and https://web.archive.org/web/20190123214800/http://www.search.org/files/pdf/RNTFCSCJRI.pdf (accessed July 12, 2019).
} 
prevent employers from asking about a job applicant's criminal record until late in the hiring process. Recent work shows negative effects of such policies on labor market outcomes. ${ }^{7}$ As a consequence, overcoming initial barriers to employment remains critical for those with criminal backgrounds. Even if ban the box policies are effective at improving employment of exoffenders, only 13 states and 18 cities extend such policies to private employment (Avery, 2019).

To the extent that job assistance programs can overcome inherent barriers that exoffenders face obtaining employment, such programs could play a role in reducing criminal recidivism. This study provides results from an experimental evaluation of an intensive job assistance program aimed at improving job readiness and placements. The experiment involved 259 ex-offenders in New York. Randomization enrolled approximately half of enrollees to the intensive job assistance program while the remainder were enrolled in a standard program (offering less intensive job-readiness skills and self-directed job search). Job assistance sessions were administered on a rolling basis between June 2009 and December 2010. Of the initial 259 participants, 219 were linked to administrative arrest records obtained through July 2012, meaning our study follows participants for 18 to 36 months after the randomized intervention.

The intensive program was administered by America Works, a New York-based private employment company with operations in seven states and the District of Columbia. The firm has more than 30 years of experience providing job assistance programs to groups that typically face significant barriers in the labor market. The program consists of intensive, short-term jobreadiness training, job placement, re-placement in cases where the initial placement does not last, and regular follow-up and support for six months to ensure successful employment. ${ }^{8}$

Several features distinguish the America Works job assistance program from other employment programs. As with many of the chronically unemployed, overwhelming numbers of ex-offenders lack work experience, have little education, and do not know how to look for a job. The job assistance program is short-term nature (one to two weeks) with a "tough-love" approach. It stresses interpersonal communication: listening to coworkers and supervisors, following instructions, and being honest and responsive. Other "soft skills," such as time management and anger management, are also developed. For the ex-offender population, this

\footnotetext{
${ }^{7}$ Recent work finds statistical discrimination from ban the box policies, especially for young African-American men (Agan and Starr, 2018; Doleac and Hansen, 2020).

${ }^{8}$ The description of America Works programs closely follows internal memos produced by Public/Private Ventures, "Moving Men into the Mainstream: Study Brief," April 2006.
} 
training may have particular resonance, as it reinforces coping and communications skills learned in prison. America Works operates exclusively through performance-based contracts; the firm does not receive payment for services until clients are placed and retained for a stipulated period in a job. The company's contracts with New York's Human Resources Administration (HRA) and other agencies raise the likelihood that the jobs that America Works finds for its clients are good matches and that its clients are paid fairly and have opportunities to advance. The company actively engages in finding further placements if initial placements are not successful. America Works provides a guarantee to employers that it can successfully fill positions and ensures that if problems arise, employers can discuss their concerns. Given employers' reluctance to consider ex-offenders, such a guarantee may be an important impetus to hiring high-risk applicants.

Our evaluation context is relatively rare because of the randomized controlled trial (RCT). Based upon the observed participant characteristics, we find that the randomization appears to be carried out successful. The overall effect of intensive job assistance program is not statistically significant. However, there are important differences between violent and nonviolent ex-offenders. The non-violent ex-offenders respond favorably to the intensive program. Only 31 percent of non-violent ex-offenders in the intensive program were subsequently arrested during the observation period, compared with 50 percent in the standard job assistance program. In contrast, there was no statistically significant different for violent ex-offenders (45 percent versus 43 percent). We also estimate the impacts on societal costs of recidivism. The evidence supports the notion that intensive job assistance program is effective for non-violent exoffenders, but not effective for violent ex-offenders.

Section II of this paper summarizes existing evidence on reintegrating ex-offenders into society. Section III describes the aforementioned randomized controlled trial and observations from site visits. Section IV discusses various data limitations of the analysis and explains the focus on criminal recidivism. Section V provides data description and empirical results. Section VI illustrates the costs and benefits of enhanced job placement. Section VII offers concluding thoughts. 


\section{Existing Evidence on Reintegrating Ex-Offenders into Society}

As Visher et al. (2005) note, community-based employment interventions for exoffenders date as far back as the 1960s, with a series of well-known federal job-training programs following in the 1970s and 1980s, including the 1973 Comprehensive Employment and Training Act (CETA), the 1983 Job Training and Partnership Act (JTPA), and the 1998 Workforce Investment Act (WIN). However, virtually all evaluations of prisoner reentry and crime-abatement programs use nonexperimental techniques. Drake et al. (2009) identify 545 program evaluations, of which fewer than 5 percent used randomized controls. Cook et al. (2015) identify only eight randomized trials prior to theirs, and only four of these (including Cook et al. 2015) were after 2000. As a consequence, relatively few recent studies use methods comparable to our study.

Visher et al. (2005) conduct a meta-analysis of experimental evaluations of noncustodial employment programs for adult ex-offenders, where the program had to include, at a minimum, job training or placement. They note that only eight studies using random assignment could be identified in English-language publications; they characterize the knowledge about the effects of such programs as "hampered by inadequate contemporary research." The eight studies, implemented between 1971 and 1994, involved the Baltimore Living Insurance for Ex-Prisoners (LIFE); Transitional Aid Research Project (TARP); National Supported Work Demonstration (NSW), a job-training program for probationers; Job Training Partnership Act (JTPA);

JOBSTART; Job Corps; and Opportunity to Succeed (OPTS). In these studies, recidivism measures included arrests, based on official records or self-reported behavior, for periods of up to 36 months after participation in the employment program. Based on their meta-analysis, Visher et al. conclude that the "eight interventions had no significant effect on the likelihood that participants would be rearrested."

Raphael (2010) and Cook et al. (2015) discuss a number of more recent experimental studies of prisoner reentry efforts, including the Center for Employment Opportunities (CEO), based in New York City. The one-year evaluations of this program show little impact on recidivism (Bloom et al. 2007), but the second-year results showed that the treatment group was approximately 8 percentage points less likely to be convicted of a crime and 7 percent less likely to have experienced a post-release incarceration in prison or jail (Redcross et al. 2010). Raphael concludes that there is some evidence that income support, transitional employment, and human 
capital investments in ex-offenders may reduce criminal behavior and recidivism. Cook et al. (2015) evaluate an experimental study implemented by the Wisconsin Department of Corrections where "reach in" services were provided to violent offenders prior to release. They found that in the one year window of their study, the treatment group saw 0.13 fewer arrests than the control group. While the probability of being arrested within one year was lower for the treatment group, and statistically significant, the gains were modest in practical terms.

Doleac (2018) provides a comprehensive review of interventions designed to reduce recidivism and to promote employment, housing and health improvements among released felons. In general, a variety of approaches toward re-employment have been pursued. Temporary or transitional jobs, often through non-profit organizations, have been examined by Valentine, Jacobs and Redcross (2015) who find little impact on employment or recidivism. Similarly, Cook et al (2015) examine a transitional jobs program with more comprehensive services and find short term employment significantly higher under the treatment, but longer run employment does not appear to be effected. Bond et al. (2015) examine an intensive placement services program and finds significant effects on employment, but insignificant effects on recidivism. In contrast, Redcross, Barden and Bloom (2016) find that while employment effects of a transitional jobs demonstration were short run, recidivism was reduced.

Several key points should be kept in mind about existing experimental literature. First, almost all the studies are quite dated; the most recent study in Visher et al.'s meta-analysis was from 1999. They note that the lack of federal funding for ex-offender programs in the 1980s created a gap in the development and implementation of such programs. Second, the types of offenses and number of arrests may matter for the efficacy of employment services. The OPTS program, initiated in 1994, targeted ex-offenders with histories of alcohol and drug offenses. The LIFE program targeted those with high likelihoods of future arrest for property crimes and no history of drug or alcohol dependence. The NSW evaluation distinguished drug addicts from exoffenders.

Reintegrating ex-offenders back into mainstream employment has provided motivation for recent "ban the box" policies. Nationwide, 35 states and over 150 cities and counties have adopted such policies which remove conviction history from job applications and delay background checks until later in the hiring process (Avery, 2019). However, such requirements are less frequent for private employment, where only 13 states and 18 cities have such policies. 
Such laws have become increasing popular in the last 10 years; prior to 2010, only two states had such policies. There is a growing literature that has examined these policies using the quasiexperimental variation created across geography and over time. Recent work examines callback rates in field experiments (Agan and Starr, 2018), and employment with observational data (Doleac and Hansen, 2020). Other work has directly examined employment outcomes for those with criminal histories with administrative data (Jackson and Zhao, 2017; Rose 2018).

Unfortunately, ban the box policies appear to be ineffective at improving employment outcomes, and other policies that directly address employers' concerns about ex-offenders are likely to be more effective (Doleac, 2019).

This paper contributes to existing knowledge in several ways. The America Works RCT is relatively recent compared with other published experimental estimates; the experimental intervention occurred in 2009 and 2010, with recidivism measured through 2012. The experiment examines the impact a costly short-term intervention - improving job readiness for ex-offenders. We find heterogeneous effects based on offenders' arrest histories (violent from non-violent).

\section{Understanding the America Works Intervention}

\section{Description of the Randomized Control Trial}

The RCT was overseen by Public/Private Ventures (P/PV), a nonprofit, nonpartisan, social research and policy organization whose mission was to improve the effectiveness of policies, programs, and community initiatives, especially as they affect vulnerable communities, at the America Works offices in 2009 and $2010 .^{9}$

Recruitment of this study's 259 participants (which includes 254 ex-offenders and 5 hardship cases) took place at the New York offices of America Works from June 15, 2009, to December 17, 2010. Participants were all men who had been released from a prison, jail, or youth correctional facility within six months prior to their acceptance in the program. When a potential participant was identified, America Works described its program and completed typical intake procedures. America Works explained that a study of the program was being conducted and that participants had a 50/50 chance of receiving "intensive" job assistance, while other

\footnotetext{
${ }^{9}$ The discussion in this section follows directly from P/PV's document “AW Study Rationale Brief," August 2006.
} 
participants would receive "typical" job assistance. America Works then distributed written informed consent forms to potential participants.

This RCT therefore aims to increase knowledge about the effectiveness of rapid attachment to the labor market; given data constraints discussed later, the analysis here examines the causal effect of intensive job assistance services on criminal recidivism. Although the underlying causal mechanism is that such intensive assistance leads to better labor-market outcomes and less dependence on government programs - both of which, in turn, lead to reductions in recidivism - it is more difficult to convincingly examine intermediate steps due to data availability.

Both the intensive job assistance program and the standard program were administered by America Works. The intensive program included job-readiness training, job placement, and job retention. The program typically lasted two weeks with nearly daily training. The training typically focused on developing self-presentation skills through interview rehearsals and résumé preparation. The training also included work on following directions and communications with supervisors and co-workers. Following training, America Works arranges job interviews with employers and, when the placement is made, stays in contact with new hires and their employers for six months. The intensive job assistance program is unique, but well established. The combination of both intensive training and the intensive placement and follow up services is likely extremely important, and we describe some of the details of the program below. While this study is unique in examining the role of this program, we are limited in that we cannot differentiate the importance of the individual aspects of the program.

The key difference between the treatment and control group is the scope and focus of services offered. P/PV documentation described enhanced services as: (1) intensive job-readiness training, (2) rapid-attachment job-placement services, and (3) retention services. Typical services involved: (1) job-readiness training and (2) self-directed job-search assistance. ${ }^{10}$

\footnotetext{
${ }^{10}$ On its website, America Works describes four steps that it takes to get program participants back to full-time work rapidly. One step is a job-readiness program focusing on the "hard" and "soft" skills that employers are looking for. A second is sending participants to interviews and matching them with specific jobs. A third is continuing support for the participant after he finds a job (i.e., have a case manager follow up to ensure that the client is getting to work on time each day). A final step is working with participants to ensure that they are taking advantage of opportunities to increase their human capital (work-training programs, GED classes, etc.). See https://web.archive.org/web/20160128180716/http://www.americaworks.com/partners/how-we-work (accessed July 12, 2019).
} 


\section{Findings from Site Visits}

During the initial evaluation, P/PV conducted a set of site visits to better understand the "black box" of intensive job search assistance at America Works. We have reviewed 105 pages of protocols and notes from 29 separate documents from site visits conducted between November 7-9, 2005 to three separate America Works offices in the Bronx, Queens, and Manhattan.

Standard job search assistance allows the client use of the resources at America Works (AW), but is self-directed. Resources include job listings and access to computers and telephones. The director of one AW office noted: "They can go online and look for jobs and newspapers and we get the employment weekly and using monster.com. We have a resource room. Participants use them. The internet is the most popular." Given the limited resources of AW clients, this increased accessibility potentially leads to jobs. However, one placement specialist noted that at the AW office "there's only two phones and four computers. Not 50-60 people are going to use those computers. Some clients have to wait to use the computer." Moreover, client motivation is critical to placement success. The same placement specialist noted "Depending on the client, there are a couple that don't want to do anything but a lot of others use the newspapers and use the computer to come in and look for work."

Intensive job search assistance provides a comprehensive package of services. There are many differences from standard job search assistance, but one key difference is the follow-up and communication with the employer partners in the intensive program, and value the long-run relationship with employer partners. AW is well-incentivized to successfully place clients because it is a for-profit company with performance-based contracts. As a consequence, the "intensive" product consists of standard inputs into job search and also the culture at AW, which may be thought of as the intensity.

The director of one AW office describes the intensive package of services as: orientation/basic skills testing, then training, then job placement. Many hard-to-quantify features enter into the intensive program. For example, AW's "hands on" services focus on the barriers their clients encounter in obtaining jobs. These include language obstacles (most of AW's employees are bilingual) and case management (difficulties with child care, transportation, and parole officers). AW's intensive program lowers the barriers for their clients to be successful at 
jobs. For example the director mentioned "I tell the parole officers, 'Use us instead of using you' (to be the hammer making things happen with a client) and I tell them (officers) we'll call you with updates) and the employers will call you." The "hands on" approach is also reflected in AW employees having an open-door policy with clients, and providing cell phone numbers that clients can reach them after-hours.

In the intensive program, barriers are lowered, for example, by the office director personally reviewing the client's resume. "I do all the resumes here because I really believe all the candidates need a really good one. I want them to have one, that if it came across my desk, how would I want it to look. It's our name (America Works) - and I want it to look good. We demand them to dress perfectly for an interview."

The key theme, however, that was highlighted in virtually all site interviews was the long-run relationship between AW and employers. The AW performance-based contracts with intensive training provide stronger incentive for successful placements. Essentially, AW screens clients based on skills, personality, motivation and background for each job placement, and matches with employers where the likelihood of a long-run match is high. The employer partners that $\mathrm{AW}$ interacts with desire reliable employees who will not create undue risk and are willing to work long-term. As a consequence, some AW clients - such as those with extensive criminal backgrounds or violent histories - may not be suitable matches for many employers. One employer partner describes AW's reputation relative to other placement services: "It's nice to have somebody who's going to check everything for you. Like when we hire from outside sources, we have problems. We like to hire people with recommendations." The employer goes on to mention "You know, we walk into homes that are million-dollar homes ... that's a liability for us. So it's nice to have somebody who checks their background from us" and "It's important to us they understand they know what they are getting into. We don't like people leaving after a week or two."

In addition, AW provides follow-up after job placement, which the director calls "roster management", another key difference between intensive and standard assistance. "We set up a roster-management system, because we have to stop all bad things from happening for those individuals - there are important things HRA has to know about because HRA has multiple job centers that are really welfare officers and those case managers there don't have a clue what's been going on with the client. So it creates centralized case management database with HRA." 
The control group that gets standard job search assistance does not get such follow-up with roster management: "I don't like to see candidates stagnate which is an issue with this study because the control group will be allowed to stagnate." As an example of roster management, the director mentioned "(the sales director is) talking to an employer and saying (an AW client) will begin as a home health aid on Tuesday and I'm going to give you the name of follow-up person and then we find out if there are any transportation problems, and we can call the client and find out how it's going. Every candidate has our cell phone number."

\section{Research Questions: Opportunities and Limitations}

Although P/PV successfully carried out the randomized intervention of enhanced job placement at the offices of America Works, collecting baseline demographic and socioeconomic data at the time of the trial as well, P/PV was unable to gather data on certain outcomes that might have resulted from the intervention-outcomes pertaining to the labor market, use of government welfare programs, and criminal activity. Such data are necessary to determine if enhanced services have beneficial effects in those areas. Although gathering data on welfare use and labor-market outcomes was deemed infeasible, we were able to obtain comprehensive data on criminal histories, both before and after the experimental intervention. Criminal history record searches were conducted through the New York State Unified Court System in early August 2012. The court system website describes the record search:

"The New York State Office of Court Administration (OCA) provides a New York Statewide criminal history record search (CHRS) for a fee of \$65.00. ${ }^{11}$ One can submit a CHRS request via the on-line Direct Access program or by mailing in a CHRS application form. The search criteria are based on an exact match of Name and date of birth. The search results are public records relating to open/pending and convictions in criminal cases originating from courts of all 62 counties. "

We obtained criminal histories for felony and misdemeanor cases that occurred in New York for the study's 259 participants; the analysis uses 219 participants with successful links between the data sources. Although criminal history records are available from all counties, initial data

\footnotetext{
${ }^{11}$ See https://web.archive.org/web/20180510010201/http://ww2.nycourts.gov/apps/chrs/index.shtml (accessed July 12, 2019).
} 
collection started at different points in time (from 1978 to 1993).

\section{Data Description and Recidivism Results}

\section{Data Description}

Data provided on the ex-offenders derive from two main sources. The primary source, which identifies ex-offenders in the experiment, is the baseline survey administered at the initial intake interview, as well as information on whether individuals were assigned to the intensive job assistance program (treatment group) or the standard program (control group). While data collected by P/PV concerning the treatment and control groups are complete, the baseline survey data were often incomplete, with many missing observations on specific questions. The primary data were then matched to public records on arrests and convictions (primarily from New York State) to form a criminal history of each participant. That history starts prior to the experiment and ends in July 2012.

As noted, 259 ex-offenders were enlisted for the study (including five "hardship cases"). They joined the study on a rolling basis from June 15, 2009, to December 17, 2010, with 130 in the treatment group and 129 in the control group. From this initial group of 259 ex-offenders, we were able to obtain accurate redacted arrest records for 219 of them, using public records from New York's OCA. Overall, 1,027 pages of arrest records were collected for the 219 individuals. Because arrest records for the remaining 40 ex-offenders could not be found, those individuals were excluded from the analysis. The original randomization resulted in $50.2 \%$ of the participants assigned to the treatment group (130/259). After merging with arrest records, 50.2\% $(110 / 219)$ of the remaining observations are in the treatment group.

Appendix Table 1 examines whether the 40 individuals for whom arrest records were unavailable have any significant differences in either treatment group or control variables. We regress an indicator for inclusion in the cases above on three sets of control variables. In all three models the regressions were insignificant (F-tests well below conventional rejection levels, reported in last row). While not reported here, additional robustness tests for all main results were performed by using Heckman sample selection models. Since the first stage - reported in Appendix Table 1 - has no explanatory power, it is unsurprising that the results were robust to controlling for selection. We found no evidence of selection into finding arrest records. 
Using these detailed arrest records, the 219 remaining participants in the study were organized into two categories based on criminal acts prior to enrollment in the America Works experiment: Violent ex-offenders and non-violent ex-offenders. When classifying study participants in these two groups, we assumed a hierarchical structure under which an individual was included in only one group. If the individual had been arrested for a violent crime and a property crime, he would be classified in the violent bin. Violent ex-offenders were defined as those who had committed any violent crime, as defined by the FBI Uniform Crime Reports, prior to participating in the America Works experiment. Under that definition, violent crime includes murder, rape/sexual assault, assault, and robbery. Non-violent ex-offenders include those who committed crimes against another person's property (burglary, grand larceny, trespassing, etc.), drug ex-offenders who had been convicted of selling or possessing controlled substances, and petty crimes including traffic/motor vehicle violations, criminal contempt, and harassment.

\section{Summary Statistics}

We create several variables that align arrests (or charges) with the timing of the experimental intervention that was rolled out from June 2009 to December 2010. We create variables for whether the participant was subsequently arrested, as well as the number of arrests, and for instances when demographics were missing from the baseline survey, we replaced the variable with imputation methods described below (in the regressions).

An important, necessary step for causal inference is confidence that the experimental intervention was assigned randomly. We explore this in Table 1, where we examine the relationship between being assigned to the treatment group and the control variables. With minor exceptions, the individual covariates appear unrelated to assignment of experimental treatment to intensive job assistance. We estimate the model for the full sample, as well as each of the subgroups: violent and non-violent offenders. In all three models, the F-tests of significance of the characteristics to predict the treatment (see last row) were well below conventional rejection levels. We cannot reject the null that the characteristics as a whole do not predict treatment status. Additionally, we performed a joint multi-variate test comparing the treatment and control

group characteristics, the $F(21,195)$ test statistic was 0.71 which has a p-value of 0.82 . We accept the null that the means of these characteristics are not different across the two treatment categories. There is no evidence against random assignment of treatment. 
We show summary statistics on arrests and baseline demographics in Table 2, for the full sample, as well as violent and non-violent ex-offenders. Recidivism - defined as being arrested after the experimental intervention - was observed for at least 18 months and as many as 36 months after the intervention. The earliest participants (enrolled in June 2009) were observed for the full 36 months while the latest participants (enrolled in December 2010) were only observed for 18 months. Criminal histories were obtained in early August 2012; in the analysis below, the cutoff for being observed is July 31, 2012. We have also tested, and the average length of observation is not different between the treatment and control group.

A baseline survey was administered to all participants regardless of assignment of standard or intensive job assistance. It asked straightforward demographic and socioeconomic questions, as well as asking respondents to self-report their criminal histories, participation in prison programs, and substance abuse/mental health.

The average age of ex-offenders was 39, with little variation across treatment and control groups. Only 7.4 percent of participants were married: those in the control group were slightly more likely to be married ( 8.3 percent) than those in the treatment group ( 6.4 percent). Many respondents did not provide an answer for education level; only 129 (58 percent) of ex-offenders responded. Of those who did, over 72 percent reported having a high school or high schoolequivalent degree, with the treatment group having a slightly higher rate, nearly 74 percent.

Non-response to race/ethnicity was also high, with 136 ex-offenders providing an answer. The vast majority (over 73 percent) reported African-American/black and over 23 percent reported Hispanic. Nearly 73 percent of ex-offenders possessed some kind of vocational training, and more than 60 percent had participated in job-training programs (of which nearly 42 percent participated while in prison). Fully 62 percent of the ex-offenders participated in a prerelease program. Nearly 73 percent reported receiving drug or alcohol treatment. The demographics from baseline survey makes clear that this group would struggle to obtain work.

Criminal histories were obtained from public records in New York State and merged with data collected by P/PV. Since criminal histories were limited to arrests and charges in New York, they represent an understatement if arrests and charges occurred in other states or were associated with aliases not linked to the individual. For both the treatment and control group, participants had approximately 6 arrests prior to the intervention. 
Overall, as can be seen in the last row of Table 2, fully $70 \%$ of our observations had at least one missing value for these covariates. In order to address this, we used the multiple imputation procedure in Stata. This procedure first estimates models for each of the missing variables. Logit models were used in this step. The multiple imputation procedure then generates imputations which include randomness comparable to that of the observed data (for example, for a dummy variable, the first stage model provides the predicted probability for each observation, Stata then draws from a Bernoulli using those probabilities). The model is then estimated using these imputations. The procedure is repeated, to arrive at multiple estimates and Rubin's Rule is used to combine the estimates and estimate the standard errors. The Rubin's Rule standard errors reflect not only the usual sampling variation, but variation due to the imputation approach as well. All estimates reported here using covariates employ this approach (including appendix tables). While not reported here, three other approaches were considered: complete case, replacing the missing data with the sample mean, and replacing the missing data with the sample mean and including a dummy indicating missing data. All results are robust across these approaches.

\section{Recidivism and Number of Arrests}

In our first set of regressions in Table 3, we examine the likelihood of subsequently getting arrested after the job assistance intervention. In all columns, we estimate linear probability models with heteroscedasticity-consistent standard errors. For the full sample, in column 1, the overall re-arrest rate is $47.5 \%$. Intensive job assistance insignificantly lowers the arrest rate 7.7 percentage points. In columns 2 and 3, we separate the sample of ex-offenders into the violent (126) and non-violent (93) groups based on their arrest record prior to treatment. The impact of intensive job assistance on arrest rates of violent ex-offenders is insignificant and substantively small; the coefficient estimate would imply a reduction in the likelihood of arrest of 1.6 percentage points from a mean of $51.4 \%$. For non-violent ex-offenders, intensive job assistance causes a 16.5 percentage point reduction in the likelihood of getting arrested, from a mean of 43.6\%. The latter two columns show an economically important difference in the impact of the intervention based on the nature of the offense.

In essence, our findings show that moderately-costly intensive job assistance is effective for ex-offenders who might be easier to re-integrate into the labor force in the first place (non- 
violent ex-offenders), which in turn would lead to higher (unobserved) labor force participation and lower observed recidivism (Schnepel, 2018; Yang, 2017). In contrast, it may be the case that such training leads to less successful re-integration into the labor force for violent ex-offenders who pose substantially more downside risk to the firm, or it may be that possible the relationship between labor force participation and recidivism is fundamentally weaker for those with violent histories.

In columns (4)-(5), we add individual covariates to the recidivism model for violent and nonviolent ex-offenders. We include number of pre-intervention arrests, age, marital status, education, drug/alcohol treatment, race/ethnicity, and various training programs that could be done in prison. Most of these individual characteristics insignificantly affect the likelihood of recidivism for violent ex-offenders, and their inclusion does not affect the findings about the ineffectiveness of intensive job assistance. However, the overall explanatory power of the model increases (via R-squared). The coefficient estimate for non-violent ex-offenders becomes statistically significant, but the magnitude does not change substantively and is consistent with the premise that treatment was random. The one noteworthy result is that the number of arrests prior to the intervention is strongly related to subsequent recidivism; each additional arrest raises likelihood of recidivism by 3.6 percentage points (and violent ex-offenders have, on average, 6.1 prior arrests). For non-violent ex-offenders, the impact of intensive job assistance is slightly larger, reducing the likelihood of recidivism by 19.2 percentage points ( $\mathrm{p}=0.07$ ). Few of the individual characteristics appear to affect recidivism, although each additional arrest prior to the intervention raises the likelihood of recidivism by 3.4 percentage points (and they have, on average, 5.9 prior arrests).

Finally, in columns (6)-(7), we use regression-adjusted inverse probability weighted average treatment effect estimators. This approach offers the advantage of both a more flexible functional form (through the regression adjustment), and reweighting by any differences in treatment assignment characteristics (through the inverse probability weights). We include the same covariates as in columns (4) and (5). For violent ex-offenders in column (6), the treatment effects model again shows a small and insignificant reduction in recidivism (of 3.2 percentage points, $\mathrm{p}=0.75$ ). For non-violent ex-offenders in column (7), we observe a reduction in recidivism of 18.1 percentage points $(\mathrm{p}=0.066)$, very similar to the regression results in column (5). 
We next examine the number of post-intervention arrests in Table 4. We note that coefficient estimates here may be less comparable for violent and non-violent offenders, if violent offenders are likely to be re-arrested for more serious offenses, and as a consequence, to be incarcerated for longer periods of time in the post-intervention period, thus having fewer chances to be rearrested. We estimate Tobit models since nearly half the sample are not re-arrested (and thus have a zero) during our window (see Table 2). This constitutes a censored model. Our results are shown for the full sample in column (1), as well as separated for violent (column 2 and 4) and non-violent (column 3 and 5) ex-offenders (both with and without individual covariates). In the simple models with no covariates, the coefficient on treatment is -0.63 for violent offenders and 0.83 for non-violent offenders. When control variables are included, the coefficient on violent offenders is -0.16 while the coefficient on non-violent offenders is -1.04 with a p-value of 0.040 . Like arrests, we find evidence that the treatment reduces recidivism for the non-violent offenders, but no evidence of that claim for the violent offenders.

We have performed a number of robustness checks. ${ }^{12}$ First, we estimate the full regression model for any arrest without including observations where the control variables were imputed. The exercise reduces sample size, and as expected, statistical significance. However, the estimate of the treatment coefficient for non-violent ex-offenders remains negative (and larger at -0.52), while the estimate for the treatment effect for violent ex-offenders is positive at 0.05 . We also estimate a logit model for the arrests and obtain a marginal effect of -0.14 for the non-violent exoffenders with a p-value of 0.055 , while the estimated marginal effect for the violent offenders is insignificant and small at 0.004. A number of different options for estimation of treatment effects, such as inverse probability weighting, matching and regression adjustment, were considered. Under the assumption of random assignment, all should be equivalent estimators to the simple differences in means. Regression adjusting (as in the OLS estimates), increased statistical significance, but little impact on magnitudes. Other approaches had similar impact on effects, but varied in precision, as would be expected. In summary, our results appear to be quite robust to a number of modeling decisions.

\footnotetext{
${ }^{12}$ All output from the robustness checks is available from the authors.
} 


\section{Costs and Benefits of Enhanced Job Placement}

The principal finding is best captured in the recidivism measures. However, given that it costs approximately $\$ 5,000$ to place someone in a job through an intensive America Works job assistance program, it is important to obtain some estimate of the social benefit of the reduction in arrests. ${ }^{13}$ Establishing social costs of crime is challenging. We use existing studies, along with the nature of the arrest and charges, to assign a dollar value for each crime committed by an exoffender, both pre- and post-treatment. Appendix Table 2 summarizes the estimated social costs for various crime categories from eight different studies. The social costs for violent crimes especially murder - are extremely high, while many nonviolent crimes impose relatively modest social costs. In the following analysis, we rely on estimates in comprehensive studies by Cohen and Piquero (2009) and McCollister et al. (2010).

Our analysis proceeds in several steps. First, we know all charges (both pre- and postintervention) from the arrest records for the 219 successfully merged individuals. We classify the charges related with arrests (type and quantity) in terms of FBI classifications for crimes, including several miscellaneous categories. Second, each charge associated with an arrest was assigned a social cost value derived from Cohen and Piquero (2009), which is column 4 in Appendix Table 2. This study was chosen because it had the most comprehensive list of social costs for crimes out of the eight studies. When a cost estimate was unavailable, we used estimates from McCollister et al. (2010). This allowed us to additionally provide social costs for household crimes, embezzlement, stolen property, and forgery and counterfeiting. Many of the estimates by crime category are fairly similar, with the notable exception of murder (where we use a social cost of crime of $\$ 4.6$ million for the 30 recorded murders/other charges related to loss of life from Cohen and Piquero (2009) rather than \$9.0 million from McColister et al. (2010)). Finally, based on the social costs associated with the charges, we compute the total social cost of crime (both pre- and post-treatment).

We observed in Table 3 that recidivism fell for non-violent offenders, and that total arrests were responsive to the intervention in Table 4. However, the analysis is silent on whether the nature of crimes committed changed due to the intensive job training. One important assumption in the crime analysis - for recidivism, arrests, or especially for the social cost of

\footnotetext{
${ }^{13}$ For the cost estimate on the intensive job placement program from America Works, see Cove (2013).
} 
crime - is that arrests reflect the underlying crime on the ground. To the extent that arrest rates differed by individual covariates (for example, by race, where we expect that African-American men might be arrested at greater rates for the same offense than white men), it may well be the case that we misstate the social cost of crime. However, Table 4 suggests no difference in arrests within this sample by race/ethnicity, nor is the experimental intervention of intensive job training differentially administered by race.

For the full sample, the social cost of crimes committed post-treatment was approximately $\$ 103,000$. For the roughly half of ex-offenders who were re-arrested, the average social cost exceed $\$ 219,000$. The median social cost, conditional on arrest, is $\$ 7,500$, while the $75^{\text {th }}$ percentile exceeds $\$ 230,000$. Assuming that arrests reflect overall crime activity, a significant percentage of ex-offenders who get arrested impose large societal costs. Given the large number of zeros in our data (due to not being arrested), Table 5 estimates Tobit models (assuming zero social cost for participants without arrests). The outcome of interest is the social cost of the crimes (arrests) committed, post-treatment. For the full sample (without covariates), column (1) reveals that the intensive job assistance treatment reduced social costs by more than $\$ 151,000$ ( $\mathrm{p}=0.12$, with 116 left-censored observations out of 219). The reduced cost is much lower for violent ex-offenders, and imprecisely estimated in column (2), while the reduced cost is much larger in magnitude - nearly $\$ 324,000$ in social costs avoided ( $\mathrm{p}=0.12)$ - for non-violent ex-offenders who received the treatment in column (3). Adding individual characteristics does change the magnitudes, but not the substantive conclusions in columns (4) and (5). For violent ex-offenders, the results are imprecise. For non-violent ex-offenders, social costs are significantly reduced by more than $\$ 436,000$ ( $\mathrm{p}=0.067)$ from the intervention. As in earlier tables, many of the covariates are weakly related to social costs. Consistent with earlier tables, the number of arrests prior to treatment - for both violent and non-violent ex-offenders significantly increases subsequent social costs after the treatment.

These results help establish the cost-benefit analysis of the America Works program. Treatment cost for one ex-offender in the intensive program is approximately $\$ 5,000$ (Cove, 2013), meaning this is also the upper bound on the marginal cost of the intensive intervention. While caution should be taken in using these estimates, the overall result is striking: providing intensive job-training and job-search services to non-violent ex-offenders more than pays for 
itself by reducing the social costs of crime. However, there is little evidence that such treatment affects violent ex-offenders.

\section{Conclusion}

This paper examines the impact of intensive job-readiness training and job-search assistance on criminal recidivism and labor-market outcomes among ex-offenders, using data from a randomized controlled trial conducted at the America Works job-placement agency. Overall, such training and assistance had no effect on recidivism. This result nonetheless masks substantial heterogeneity of outcomes.

For the roughly half of program participants with nonviolent arrest histories, intensive job-search assistance significantly decreased the likelihood of recidivism. Only 31 percent of nonviolent offenders receiving intensive job training were subsequently rearrested; among participants receiving standard training, on the other hand, 50 percent were subsequently rearrested. Such results suggest that enhanced job-search assistance is most effective for the easiest of the hard-to-serve population (i.e., those without histories of violence and few charges) and far less effective for clients with more difficult histories of arrests and charges.

Although these results on criminal recidivism are noteworthy, we were unable to answer a number of other important questions originally posed when P/PV set up the experiment, including: (1) Did participation in America Works intensive job assistance program increase exoffenders' likelihood of finding and maintaining employment over those who did not receive intensive services? (2) Did the intensive program help ex-offenders find jobs of a higher quality than they would otherwise have found on their own? (3) Did participation in the intensive program reduce reliance on cash assistance from the government? (4) Did participation increase formal participation in the child-support system? Data constraints preclude us from answering these questions. To address them, we would require high-quality administrative data or the opportunity to re-interview ex-offenders many years after initial contact with America Works. Such approaches, while conceptually possible, are difficult, given budgetary and privacy constraints.

Two of additional limitations should be acknowledged. First, the program took place during the Great Recession. It is possible that this reduced the effectiveness of the program. 
Second, the size of the experiment was modest and clearly impacted the conclusions we could draw. Further there was some attrition from the data collection process which may be important.

Nonetheless, this paper's findings on recidivism suggest that the obvious path to improvement in the lives of ex-offenders - as well as the welfare of society at large - runs through the labor market. 


\section{References}

Agan, Amanda, and Sonja Starr. 2017. "The Effect of Criminal Records on Access to Employment." American Economic Review 107(5): 560-4.

—. 2018. "Ban the Box, Criminal Records, and Racial Discrimination: A Field Experiment." The Quarterly Journal of Economics 133(1): 191-235.

Aos, Steve, Polly Phipps, Robert Barnoski, and Roxanne Lieb. 2001. The Comparative Costs and Benefits of Programs to Reduce Crime. Document Number 01-05-1201. Olympia: Washington State Institute for Public Policy, http://wsipp.wa.gov/ReportFile/756/Wsipp_TheComparative-Costs-and-Benefits-of-Programs-to-Reduce-Crime-v-4-0_Full-Report.pdf (accessed July 10, 2019).

Avery, Beth. 2019. "Ban the Box: U.S. Cities, Counties, and States Adopt Fair-Chance Policies to Advance Employment Opportunities for People with Past Convictions." Working Paper, National Employment Law Project, https://s27147.pcdn.co/wp-content/uploads/Ban-the-BoxFair-Chance-State-and-Local-Guide-July-2019.pdf (accessed July 10, 2019).

Beck, Allen J., and Bernard E. Shipley. 1989. "Recidivism of Prisoners Released in 1983." U.S. Department of Justice, Office of Justice Programs, Bureau of Justice Statistics, http://www.bjs.gov/content/pub/pdf/rpr83.pdf (accessed July 10, 2019).

Bloom, Dan, Cindy Redcross, Janine Zweig, and Gilda Azurdia. 2007. "Transitional Jobs for ExPrisoners: Early Impacts from a Random Assignment Evaluation of the Center for Employment Opportunities Prisoner Reentry Program.” Manpower Demonstration Research Corporation Working Paper.

Bond, Gary R., Sunny Jung Kim, Deborah R. Becker, Sarah J. Swanson, Robert E. Drake, Izabela M. Krzos, Virginia V. Fraser, Sheila O’Neill, and Rochelle L. Frounfelker. 2015. “A Controlled Trial of Supported Employment for People With Severe Mental Illness and Justice Involvement." Psychiatric Services, 66: 1027-1034.

Bushway, Shawn. 1996. "Labor Market Effects of Permitting Employer Access to Criminal History Records.” Working Paper, University of Maryland.

— , and Robert Apel. 2012. "A Signaling Perspective on Employment-Based Reentry Programming." Criminology and Public Policy 11(1): 21-50.

Carson, E. Ann, and William J. Sabol. 2012. "Prisoners in 2011." U.S. Department of Justice, Office of Justice Programs, Bureau of Justice Statistics, http://www.bjs.gov/content/pub/pdf/p11.pdf (accessed July 10, 2019).

Cohen, Mark A. 1988. "Pain, Suffering, and Jury Awards: A Study of the Cost of Crime to Victims." Law \& Society Review 22(3): 537-56.

— , Roland T. Rust, Sara Steen, and Simon T. Tidd. 2004. "Willingness-to-Pay for Crime Control Programs." Criminology 42(1): 89-110.

Cohen, Mark A., and Alex R. Piquero. 2009. "New Evidence on the Monetary Value of Saving a High Risk Youth.” Journal of Quantitative Criminology 25(1): 25-49.

Cook, Philip J., Songman Kang, Anthony A. Braga, Jens Ludwig, and Mallory E. O’Brien. 2015. "An Experimental Evaluation of a Comprehensive Employment-Oriented Prisoner Re-entry Program." Journal of Quantitative Criminology, 31: 355-382.

Connerley, Mary L., Richard D. Arvey, and Charles J. Bernardy. 2001. "Criminal Background Checks for Prospective and Current Employees: Current Practices among Municipal Agencies." Public Personnel Management 20(2): 173-83. 
Cove, Peter. 2013. "Let's Trade Prison Beds for Work." http://www.realclearpolicy.com/articles/2013/05/16/lets_trade_prison_beds_for_work_513.ht $\underline{\mathrm{ml}}$ (accessed September 30, 2020).

Doleac, Jennifer L. 2018. "Strategies to productively reincorporate the formerly-incarcerated into communities: A review of the literature." http://ftp.iza.org/dp11646.pdf

Doleac, Jennifer L. 2019. "Empirical Evidence on the effects of Ban the Box policies: The state of the literature in 2019. Testimony prepared for the U.S. House Committee on Oversight and Government Reform." Working paper, http://jenniferdoleac.com/wpcontent/uploads/2019/03/Doleac testimony_BTB_2019.pdf (accessed July 12, 2019).

Doleac, Jennifer L., and Benjamin Hansen. 2020. "The Unintended Consequences of 'Ban the Box': Statistical Discrimination and Employment Outcomes when Criminal Histories Are Hidden." Journal of Labor Economics. 38(2): 321-74.

Drake, Elizabeth, Steve Aos, and Marna Miller. 2009. "Evidence-Based Public Policy Options to Reduce Crime and Criminal Justice Costs: Implications in Washington State.” Victims and Offenders 4(2): 170-96.

Freeman, Richard. 1992. "Crime and the Employment of Disadvantaged Youths." In Urban Labor Markets and Job Opportunities, ed. George Peterson and Wayne Vroman. Washington D.C.: Urban Institute.

Glynn, T. P. 1988. "The Limited Viability of Negligent Supervision, Retention, Hiring and Infliction of Emotional Distress Claims in Employment Discrimination Cases in Minnesota.” William Mitchell Law Review.

Hahn, Jeffrey M. 1991. "Pre-Employment Information Services: Employers Beware." Employee Relations Law Journal 17(1): 45-69.

Harer, Miles D. 1994. "Recidivism among Federal Prisoners Released in 1987." Journal of Correctional Education 46(3): 98-127.

Harlow, Caroline Wolf. 2003. "Education and Correctional Populations." U.S. Department of Justice, Office of Justice Programs, Bureau of Justice Statistics Special Report, http://www.bjs.gov/content/pub/pdf/ecp.pdf (accessed July 10, 2019).

Holzer, Harry J., Steven Raphael, and Michael A. Stoll. 2003. "Employment Barriers Facing ExOffenders." Urban Institute Reentry Roundtable Discussion Paper, http://urban.org/UploadedPDF/410855 holzer.pdf (accessed July 10, 2019).

Jackson, Osborne, and Bo Zhao. 2017. "The Effect of Changing Employers' Access to Criminal Histories on Ex-Offenders' Labor Market Outcomes: Evidence from the 2010-2012 Massachusetts CORI Reform.” Federal Reserve of Boston Research Department Working Paper 16-30.

Langan, Patrick A., and David J. Levin. 2002. "Recidivism of Prisoners Released in 1994." U.S. Department of Justice, Office of Justice Programs, Bureau of Justice Statistics Special Report, http://www.bjs.gov/content/pub/pdf/rpr94.pdf (accessed July 10, 2019).

McCollister, Kathryn E., Michael T. French, and Hai Fang. 2010. "The Cost of Crime to Society: New Crime-Specific Estimates for Policy and Program Evaluation." Drug and Alcohol Dependence 108(1): 98-109.

Miller, Ted R., Mark A. Cohen, and Shelli B. Rossman. 1993. "Victim Costs of Violent Crime and Resulting Injuries." Health Affairs 12(4): 186-97.

Miller Ted R., Mark A. Cohen, and Brian Wiersema. 1996. "Victim Costs and Consequences: A New Look." National Institute of Justice Research Report, NCJ 155282. U.S. Department of Justice, https://www.ncjrs.gov/pdffiles/victcost.pdf (accessed July 10, 2019). 
Pew Center on the States. 2011. State of Recidivism: The Revolving Door of America's Prisons. Washington, D.C.: Pew Charitable Trusts.

Rajkumar, Andrew S., and Michael T. French. 1997. "Drug Abuse, Crime Costs, and the Economic Benefits of Treatment." Journal of Quantitative Criminology 13(3): 291-323.

Raphael, Steven. 2010. "Improving Employment Prospects for Former Prison Inmates: Challenges and Policy.” NBER Working Paper 15874.

Redcross, Cindy, Dan Bloom, Erin Jacobs, Michelle Manno, Sara Muller-Ravett, Kristin Seefeldt, Jennifer Yahner, Alford A. Young, Jr., and Janine Zweig, 2010, "Work After Prison: One-Year Findings from the Transitional Jobs Reentry Demonstration," Mimeo, http://papers.ssrn.com/sol3/papers.cfm?abstract_id=1786932 (accessed July 10, 2019).

Redcross, Cindy, Bret Barden, and Dan Bloom. 2016. "The Enhanced Transitional Jobs Demonstration: Implementation and Early Impacts of the Next Generation of Subsidized Employment Programs." U.S. Department of Labor, Employment and Training Administration, https://wdr.doleta.gov/research/FullText_Documents/ETAOP-201607_The \%20Enhanced\%20Transitional\%20Jobs\%20Demonstration\%20Implementation\%20a nd $\% 20$ Early $\% 20$ Impacts $\% 20$ of $\% 20$ the $\% 20$ Next $\% 20$ Generation $\% 20$ of $\% 20$ Subsidized $\% 20 \mathrm{E}$ mployment\%20Programs.pdf , accessed July 2020.

Rose, Evan. 2018. "Does Banning the Box Help Ex-Offenders Get Jobs? Evaluating the Effects of a Prominent Example." Working paper, https://ekrose.github.io/files/btb_seattle_0418.pdf (accessed July 12, 2019).

Sampson, Robert J., and John H. Laub. 1997. "A Life-Course Theory of Cumulative Disadvantage and the Stability of Delinquency." In Developmental Theories of Crime and Delinquency: Advances in Criminological Theory, ed. T. Thornberry, 7:133-61. New Brunswick, N.J.: Transaction Publishers.

Schnepel, Kevin T. 2018. "Good Jobs and Recidivism." The Economic Journal 128(608): 447469.

Society for Human Resource Management. 2012. "Background Checking: The Use of Criminal Background Checks in Hiring Decisions." http://www.shrm.org/research/surveyfindings/articles/pages/criminalbackgroundcheck.aspx (accessed July 10, 2019).

Travis, Jeremy, Amy Solomon, and Michelle Waul. 2001. From Prison to Home: The Dimensions and Consequences of Prisoner Reentry. Washington D.C.: Urban Institute.

U.S. Department of Justice. 2004. "Profile of Jail Inmates 2002." Washington, D.C.: Bureau of Justice Statistics.

—. 2007. "Justice Expenditure and Employment in the United States 2005." Washington, D.C.: Bureau of Justice Statistics.

—. 2008. "Crime in the United States: Uniform Crime Reports 2007.” Washington, D.C.: Federal Bureau of Investigation.

Valentine, Erin Jacobs, and Cindy Redcross. 2015. "Transitional jobs after release from prison: effects on employment and recidivism." IZA Journal of Labor Policy, 4 (16).

Visher, Christy A., Laura Winterfield, and Mark B. Coggeshall. 2005. "Ex-Offender Employment Programs and Recidivism: A Meta-Analysis.” Journal of Experimental Criminology 1(3): 295-316.

Yang, Crystal, S. 2017. "Local Labor Markets and Criminal Recidivism." Journal of Public Economics 147(1):16-29. 


\begin{tabular}{|c|c|c|c|}
\hline \multicolumn{4}{|l|}{ s } \\
\hline & All & Violent & Non-Violent \\
\hline \multirow[t]{2}{*}{ Total Arrests, Pre-intervention } & -0.005 & -0.007 & 0.006 \\
\hline & $(0.006)$ & $(0.008)$ & $(0.010)$ \\
\hline \multirow[t]{2}{*}{ Total Days Observed (00’s) } & 0.016 & -0.003 & 0.054 \\
\hline & $(0.026)$ & $(0.033)$ & $(0.047)$ \\
\hline \multirow[t]{2}{*}{ Age } & 0.001 & 0.000 & -0.002 \\
\hline & $(0.005)$ & $(0.007)$ & $(0.009)$ \\
\hline \multirow[t]{2}{*}{ Married } & -0.003 & -0.011 & 0.036 \\
\hline & $(0.122)$ & $(0.252)$ & $(0.203)$ \\
\hline \multirow[t]{2}{*}{ Hispanic } & -0.017 & 0.018 & -0.047 \\
\hline & $(0.123)$ & $(0.208)$ & $(0.206)$ \\
\hline \multirow[t]{2}{*}{ Other Race } & 0.04 & 0.016 & 0.113 \\
\hline & $(0.110)$ & $(0.220)$ & $(0.152)$ \\
\hline \multirow[t]{2}{*}{ Disability } & 0.021 & 0.025 & -0.137 \\
\hline & $(0.145)$ & $(0.193)$ & $(0.186)$ \\
\hline \multirow[t]{2}{*}{ High School/GED Ed } & 0.016 & -0.041 & 0.01 \\
\hline & $(0.105)$ & $(0.158)$ & $(0.178)$ \\
\hline \multirow[t]{2}{*}{ Drug/Alcohol Treatment } & -0.063 & -0.026 & -0.064 \\
\hline & $(0.088)$ & $(0.131)$ & $(0.181)$ \\
\hline \multirow[t]{2}{*}{ Vocational Training } & -0.049 & 0.097 & -0.135 \\
\hline & $(0.103)$ & $(0.132)$ & $(0.202)$ \\
\hline \multirow{2}{*}{ Educational Training } & 0.038 & -0.053 & 0.063 \\
\hline & $(0.092)$ & $(0.120)$ & $(0.162)$ \\
\hline \multirow[t]{2}{*}{ Job Training } & 0.024 & -0.181 & 0.225 \\
\hline & $(0.104)$ & $(0.140)$ & $(0.158)$ \\
\hline \multirow[t]{2}{*}{ Life Skills } & -0.010 & 0.047 & -0.162 \\
\hline & $(0.098)$ & $(0.137)$ & $(0.184)$ \\
\hline \multirow[t]{2}{*}{ Religious Studies } & -0.07 & 0.01 & -0.107 \\
\hline & $(0.083)$ & $(0.104)$ & $(0.153)$ \\
\hline \multirow[t]{2}{*}{ Prisoner Assistance } & -0.035 & -0.068 & -0.13 \\
\hline & $(0.095)$ & $(0.129)$ & $(0.170)$ \\
\hline \multirow{2}{*}{ Other Self Help } & 0.08 & 0.031 & 0.222 \\
\hline & $(0.096)$ & $(0.142)$ & $(0.146)$ \\
\hline \multirow[t]{2}{*}{ Ethnic Organization } & 0.072 & -0.023 & 0.205 \\
\hline & $(0.104)$ & $(0.144)$ & $(0.201)$ \\
\hline \multirow[t]{2}{*}{ Pre-Release Program } & 0.029 & $0.265^{*}$ & -0.243 \\
\hline & $(0.092)$ & $(0.126)$ & $(0.163)$ \\
\hline Community Acts & $0.197 *$ & $0.337^{*}$ & 0.225 \\
\hline & $(0.099)$ & $(0.135)$ & $(0.183)$ \\
\hline Arts \& Crafts & 0.006 & -0.106 & 0.21 \\
\hline & $(0.108)$ & $(0.155)$ & $(0.172)$ \\
\hline Paid Work & -0.032 & 0.002 & -0.068 \\
\hline & $(0.076)$ & $(0.105)$ & $(0.127)$ \\
\hline Prior Job Training & 0.124 & $0.214^{*}$ & -0.055 \\
\hline & $(0.075)$ & $(0.099)$ & $(0.135)$ \\
\hline Any Missing & 0.021 & -0.033 & 0.092 \\
\hline & $(0.083)$ & $(0.116)$ & $(0.135)$ \\
\hline Constant & 0.279 & 0.386 & 0.144 \\
\hline & $(0.299)$ & $(0.413)$ & $(0.567)$ \\
\hline F-test & 0.69 & 1.11 & 0.82 \\
\hline $\mathrm{p}$-value of $\mathrm{F}$ & 0.85 & 0.35 & 0.70 \\
\hline $\mathrm{N}$ & 219 & 126 & 93 \\
\hline $\begin{array}{l}\text { Notes: Authors' analysis of part } \\
\text { of interest is assignment to the } \\
\text { arrests, all individual characteri } \\
\text { administrative arrest records ob } \\
\text { June } 2009 \text { and December } 2010 \text {. }\end{array}$ & $\begin{array}{l}\text { s experim } \\
\text { m (in cont } \\
\text { ke intervi } \\
\text { with date }\end{array}$ & $\begin{array}{l}\text { ear probal } \\
\text { dard assist } \\
\text { ed job ass }\end{array}$ & $\begin{array}{l}\text { where the outc } \\
\text { he exception of } \\
\text { ed from } \\
\text { ention (betwee }\end{array}$ \\
\hline
\end{tabular}




\begin{tabular}{|c|c|c|c|c|c|c|}
\hline \multicolumn{7}{|c|}{$\begin{array}{c}\text { Table } 2 \\
\text { Summary Statistics }\end{array}$} \\
\hline & \multicolumn{2}{|c|}{ Full Sample } & \multicolumn{2}{|c|}{$\begin{array}{l}\text { Standard Job } \\
\text { Assistance }\end{array}$} & \multicolumn{2}{|c|}{$\begin{array}{l}\text { Intensive Job } \\
\text { Assistance }\end{array}$} \\
\hline & $\begin{array}{l}\text { Sample } \\
\text { size }\end{array}$ & Mean & $\begin{array}{l}\text { Sample } \\
\text { size }\end{array}$ & Mean & $\begin{array}{l}\text { Sample } \\
\text { size }\end{array}$ & Mean \\
\hline Treatment Status (Intensive Job Assistance) & 219 & 0.502 & 109 & 0.000 & 110 & 1.000 \\
\hline Arrested, Post-Intervention & 219 & 0.475 & 109 & 0.514 & 110 & 0.436 \\
\hline Total Arrests, Post-Intervention & 219 & 1.068 & 109 & 1.266 & 110 & 0.873 \\
\hline Total Arrests, Pre-Intervention & 219 & 6.05 & 109 & 6.165 & 110 & 5.936 \\
\hline Violent Offender & 219 & 0.575 & 109 & 0.56 & 110 & 0.591 \\
\hline Non-Violent Offender & 219 & 0.425 & 109 & 0.44 & 110 & 0.409 \\
\hline Total Days Observed & 219 & 879.1 & 109 & 875.3 & 110 & 883 \\
\hline Age & 218 & 39.17 & 109 & 38.88 & 109 & 39.45 \\
\hline Married & 134 & 0.119 & 66 & 0.136 & 68 & 0.103 \\
\hline Black & 136 & 0.735 & 67 & 0.731 & 69 & 0.739 \\
\hline Hispanic & 136 & 0.235 & 67 & 0.239 & 69 & 0.232 \\
\hline White & 136 & 0.0221 & 67 & 0.015 & 69 & 0.029 \\
\hline Asian & 136 & 0.0074 & 67 & 0.015 & 69 & 0.000 \\
\hline American Indian & 136 & 0.0221 & 67 & 0.015 & 69 & 0.029 \\
\hline Pacific Islander & 136 & 0.0074 & 67 & 0.000 & 69 & 0.015 \\
\hline Disability & 198 & 0.091 & 97 & 0.093 & 101 & 0.089 \\
\hline High School/GED Ed & 129 & 0.721 & 64 & 0.703 & 65 & 0.738 \\
\hline Drug/Alcohol Treatment & 125 & 0.728 & 60 & 0.717 & 65 & 0.738 \\
\hline Vocational Training & 215 & 0.73 & 107 & 0.720 & 108 & 0.741 \\
\hline Educational Training & 212 & 0.608 & 106 & 0.566 & 106 & 0.651 \\
\hline Job Training & 216 & 0.616 & 106 & 0.557 & 110 & 0.673 \\
\hline Life Skills & 211 & 0.441 & 104 & 0.394 & 107 & 0.486 \\
\hline Religious Studies & 206 & 0.442 & 101 & 0.436 & 105 & 0.448 \\
\hline Prisoner Assistance & 214 & 0.327 & 106 & 0.283 & 108 & 0.37 \\
\hline Other Self Help & 217 & 0.327 & 107 & 0.262 & 110 & 0.391 \\
\hline Ethnic Organization & 213 & 0.183 & 104 & 0.135 & 109 & 0.229 \\
\hline Pre-Release Program & 216 & 0.616 & 106 & 0.557 & 110 & 0.673 \\
\hline Community Acts & 213 & 0.258 & 105 & 0.171 & 108 & 0.343 \\
\hline Arts \& Crafts & 210 & 0.167 & 105 & 0.143 & 105 & 0.19 \\
\hline Paid Work & 213 & 0.408 & 105 & 0.429 & 108 & 0.389 \\
\hline Prior Job Training & 211 & 0.417 & 105 & 0.362 & 106 & 0.472 \\
\hline Any Missing & 219 & 0.712 & 109 & 0.716 & 110 & 0.709 \\
\hline
\end{tabular}




\begin{tabular}{|c|c|c|c|c|c|c|c|}
\hline \multicolumn{6}{|c|}{$\begin{array}{c}\text { Table } 3 \\
\text { Arrested Post-Intervention? }(\mathbf{1}=\mathbf{y e s ,} \mathbf{0 = n o}) \\
\text { Linear probability model }\end{array}$} & \multicolumn{2}{|c|}{$\begin{array}{l}\text { Treatment Effects } \\
\text { Estimator }\end{array}$} \\
\hline & All & Violent & Non-Violent & Violent & Non-Violent & Violent & $\begin{array}{c}\text { Non- } \\
\text { Violent }\end{array}$ \\
\hline \multirow[t]{2}{*}{ Intensive Job Assistance } & -0.077 & -0.016 & -0.165 & -0.030 & $-0.192 *$ & 0.032 & $-0.181 *$ \\
\hline & $(0.068)$ & $(0.090)$ & $(0.103)$ & $(0.101)$ & $(0.105)$ & $(0.101)$ & $(0.099)$ \\
\hline Total Arrests, Pre- & & & & $0.036 * * *$ & $0.034 * * *$ & & \\
\hline Intervention & & & & $(0.007)$ & $(0.010)$ & & \\
\hline \multirow[t]{2}{*}{ Age } & & & & -0.007 & 0.002 & & \\
\hline & & & & $(0.006)$ & $(0.006)$ & & \\
\hline Married & & & & $\begin{array}{l}-0.071 \\
(0.246)\end{array}$ & $\begin{array}{c}0.213 \\
(0.217)\end{array}$ & & \\
\hline Hispanic & & & & $\begin{array}{l}-0.034 \\
(0.200)\end{array}$ & $\begin{array}{c}0.051 \\
(0.144)\end{array}$ & & \\
\hline Other Race & & & & $\begin{array}{c}0.096 \\
(0.193)\end{array}$ & $\begin{array}{l}-0.106 \\
(0.128)\end{array}$ & & \\
\hline Disability & & & & $\begin{array}{c}0.092 \\
(0.171)\end{array}$ & $\begin{array}{c}0.152 \\
(0.160)\end{array}$ & & \\
\hline High School/GED Ed & & & & $\begin{array}{l}-0.082 \\
(0.153)\end{array}$ & $\begin{array}{l}-0.021 \\
(0.149)\end{array}$ & & \\
\hline Drug/Alcohol Treatment & & & & $\begin{array}{l}-0.120 \\
(0.129)\end{array}$ & $\begin{array}{l}-0.155 \\
(0.136)\end{array}$ & & \\
\hline Vocational Training & & & & $\begin{array}{c}0.005 \\
(0.129)\end{array}$ & $\begin{array}{c}0.002 \\
(0.143)\end{array}$ & & \\
\hline Educational Training & & & & $\begin{array}{l}-0.091 \\
(0.126)\end{array}$ & $\begin{array}{c}0.039 \\
(0.136)\end{array}$ & & \\
\hline Job Training & & & & $\begin{array}{c}0.095 \\
(0.131)\end{array}$ & $\begin{array}{c}0.014 \\
(0.134)\end{array}$ & & \\
\hline Life Skills & & & & $\begin{array}{c}0.027 \\
(0.114)\end{array}$ & $\begin{array}{c}0.120 \\
(0.158)\end{array}$ & & \\
\hline Religious Studies & & & & $\begin{array}{c}0.023 \\
(0.111)\end{array}$ & $\begin{array}{l}-0.202^{*} \\
(0.119)\end{array}$ & & \\
\hline Prisoner Assistance & & & & $\begin{array}{c}0.009 \\
(0.132)\end{array}$ & $\begin{array}{l}-0.141 \\
(0.143)\end{array}$ & & \\
\hline Other Self Help & & & & $\begin{array}{c}0.007 \\
(0.136)\end{array}$ & $\begin{array}{c}0.120 \\
(0.141)\end{array}$ & & \\
\hline Ethnic Organization & & & & $\begin{array}{l}-0.139 \\
(0.119)\end{array}$ & $\begin{array}{c}0.064 \\
(0.154)\end{array}$ & & \\
\hline Pre-Release Program & & & & $\begin{array}{c}0.040 \\
(0.146)\end{array}$ & $\begin{array}{l}-0.163 \\
(0.130)\end{array}$ & & \\
\hline Community Acts & & & & $\begin{array}{c}0.130 \\
(0.133)\end{array}$ & $\begin{array}{c}0.108 \\
(0.146)\end{array}$ & & \\
\hline Arts \& Crafts & & & & $\begin{array}{c}0.089 \\
(0.141)\end{array}$ & $\begin{array}{l}-0.200 \\
(0.208)\end{array}$ & & \\
\hline Paid Work & & & & $\begin{array}{l}-0.025 \\
(0.111)\end{array}$ & $\begin{array}{c}0.025 \\
(0.116)\end{array}$ & & \\
\hline Prior Job Training & & & & $\begin{array}{c}0.062 \\
(0.097)\end{array}$ & $\begin{array}{c}0.186 \\
(0.112)\end{array}$ & & \\
\hline \multirow[t]{2}{*}{ Constant } & $\begin{array}{c}0.514 * * * \\
(0.048)\end{array}$ & $\begin{array}{c}0.508 * * * \\
(0.065)\end{array}$ & $\begin{array}{c}0.521 * * * \\
(0.073)\end{array}$ & $\begin{array}{c}0.596 * * \\
(0.280)\end{array}$ & $\begin{array}{c}0.409 \\
(0.303)\end{array}$ & $\begin{array}{c}0.441 \\
(0.073)\end{array}$ & $\begin{array}{c}0.509 * * * \\
(0.073)\end{array}$ \\
\hline & 0.006 & 0.0003 & 0.0277 & 0.246 & 0.357 & --- & --- \\
\hline \multicolumn{8}{|c|}{$\begin{array}{l}\text { Notes: Authors' analysis of } 219 \text { participants in the America Works experiment, with } 126 \text { violent and } 93 \text { non-violent ex- } \\
\text { offenders. Linear probability model is used in columns (1)-(5) with heteroscedasticity-consistent standard errors, and a } \\
\text { regression adjusted-inverse probability weighted treatment effects model in columns (6)-(7), where the outcome of interest is } \\
\text { whether the ex-offender was arrested any time after the experimental intervention. With the exception of pre-intervention } \\
\text { arrests, all individual characteristics are from the baseline intake interview. Pre-treatment arrests are derived from } \\
\text { administrative arrest records obtained in August } 2012 \text {, along with date of randomized job assistance intervention (between } \\
\text { June } 2009 \text { and December } 2010) . * p<0.10, * * p<0.05, * * * p<0.01 \text {. }\end{array}$} \\
\hline
\end{tabular}




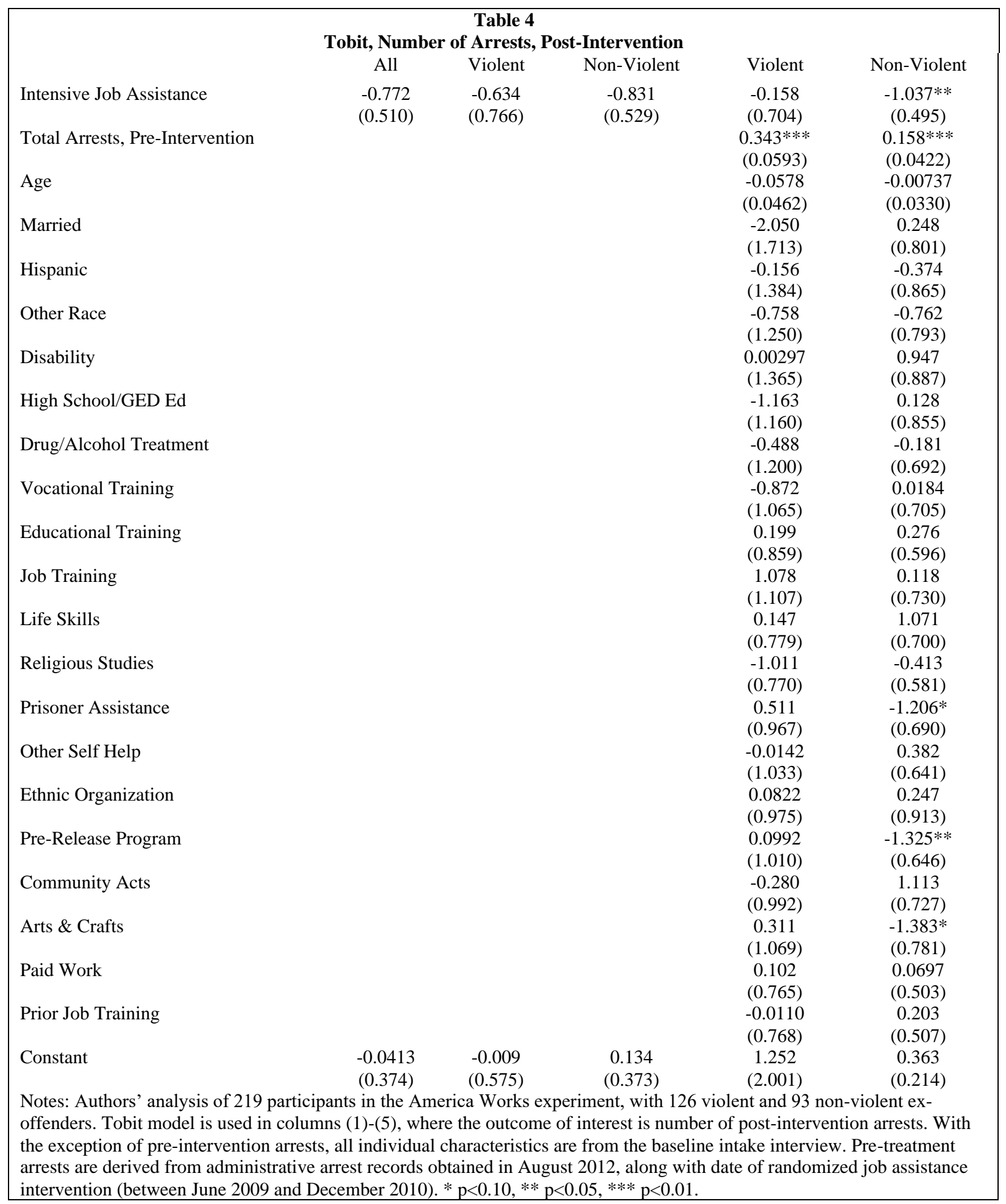




\begin{tabular}{|c|c|c|c|c|c|}
\hline \multicolumn{6}{|c|}{$\begin{array}{c}\text { Table } 5 \\
\text { Tobit, Social Cost of Arrests, Post-Intervention }\end{array}$} \\
\hline & All & Violent & Non-Violent & Violent & Non-Violent \\
\hline Intensive Job Assistance & $\begin{array}{r}-151912 \\
(97434)\end{array}$ & $\begin{array}{l}-67279 \\
(89230)\end{array}$ & $\begin{array}{l}-323917 \\
(205949)\end{array}$ & $\begin{array}{l}-16754 \\
(95163)\end{array}$ & $\begin{array}{l}-436159 * \\
(234214)\end{array}$ \\
\hline Total Arrests, Pre-Intervention & & & & $\begin{array}{c}21867 * * \\
(8440)\end{array}$ & $\begin{array}{l}41836^{* *} \\
(19452)\end{array}$ \\
\hline Age & & & & $\begin{array}{r}-10520 \\
(6434)\end{array}$ & $\begin{array}{c}-3962 \\
(15073)\end{array}$ \\
\hline Married & & & & $\begin{array}{c}11767 \\
(332718)\end{array}$ & $\begin{array}{c}87298 \\
(422191)\end{array}$ \\
\hline Hispanic & & & & $\begin{array}{l}-59511 \\
(275361)\end{array}$ & $\begin{array}{l}-178521 \\
(302100)\end{array}$ \\
\hline Other Race & & & & $\begin{array}{l}125925 \\
(223392)\end{array}$ & $\begin{array}{l}-347999 \\
(303258)\end{array}$ \\
\hline Disability & & & & $\begin{array}{c}28800 \\
(223572)\end{array}$ & $\begin{array}{c}-89915 \\
(407359)\end{array}$ \\
\hline High School/GED Ed & & & & $\begin{array}{l}-182336 \\
(202560)\end{array}$ & $\begin{array}{l}-350856 \\
(271786)\end{array}$ \\
\hline Drug/Alcohol Treatment & & & & $\begin{array}{l}-124627 \\
(195113)\end{array}$ & $\begin{array}{c}67005 \\
(324127)\end{array}$ \\
\hline Vocational Training & & & & $\begin{array}{l}-167123 \\
(128899)\end{array}$ & $\begin{array}{c}-13851 \\
(331541)\end{array}$ \\
\hline Educational Training & & & & $\begin{array}{c}71944 \\
(134117)\end{array}$ & $\begin{array}{c}336952 \\
(279632)\end{array}$ \\
\hline Job Training & & & & $\begin{array}{c}167637 \\
(149847)\end{array}$ & $\begin{array}{c}-58268 \\
(322574)\end{array}$ \\
\hline Life Skills & & & & $\begin{array}{c}-12979 \\
(110823)\end{array}$ & $\begin{array}{c}399231 \\
(368293)\end{array}$ \\
\hline Religious Studies & & & & $\begin{array}{c}-60511 \\
(107111)\end{array}$ & $\begin{array}{l}-443532 \\
(283175)\end{array}$ \\
\hline Prisoner Assistance & & & & $\begin{array}{c}82086 \\
(120257)\end{array}$ & $\begin{array}{l}-417627 \\
(331298)\end{array}$ \\
\hline Other Self Help & & & & $\begin{array}{c}16501 \\
(132226)\end{array}$ & $\begin{array}{c}230482 \\
(310842)\end{array}$ \\
\hline Ethnic Organization & & & & $\begin{array}{l}-143356 \\
(129412)\end{array}$ & $\begin{array}{c}149160 \\
(423265)\end{array}$ \\
\hline Pre-Release Program & & & & $\begin{array}{c}-88160 \\
(153797)\end{array}$ & $\begin{array}{l}-535832 * \\
(315368)\end{array}$ \\
\hline Community Acts & & & & $\begin{array}{c}32726 \\
(119522)\end{array}$ & $\begin{array}{c}61324 \\
(370593)\end{array}$ \\
\hline Arts \& Crafts & & & & $\begin{array}{c}129643 \\
(129901)\end{array}$ & $\begin{array}{l}-274939 \\
(364661)\end{array}$ \\
\hline Paid Work & & & & $\begin{array}{c}-56795 \\
(104278)\end{array}$ & $\begin{array}{l}-116456 \\
(225356)\end{array}$ \\
\hline Prior Job Training & & & & $\begin{array}{c}22021 \\
(134644)\end{array}$ & $\begin{array}{c}114917 \\
(239255)\end{array}$ \\
\hline Constant & $\begin{array}{l}-132833 \\
(71261)\end{array}$ & $\begin{array}{l}-56689 \\
(66826)\end{array}$ & $\begin{array}{c}-219198 \\
(144298)\end{array}$ & $\begin{array}{c}417632 \\
(269174)\end{array}$ & $\begin{array}{l}325644 \\
(87585)\end{array}$ \\
\hline $\begin{array}{l}\text { Notes: Authors' analysis of } 219 \\
\text { offenders. Tobit model is used } \\
\text { With the exception of pre-interv } \\
\text { treatment arrests are derived fro } \\
\text { assistance intervention (betweer }\end{array}$ & $\begin{array}{l}\text { ts in the A } \\
\text { (1)-(5), wl } \\
\text { ests, all ind } \\
\text { trative arre } \\
9 \text { and Dece }\end{array}$ & $\begin{array}{l}\text { ca Works } \\
\text { the outcor } \\
\text { lal charac } \\
\text { cords obts } \\
\text { r } 2010) . *\end{array}$ & $\begin{array}{l}\text { riment, with } 12 \\
\text { interest is socia } \\
\text { ics are from the } \\
\text { in August } 2012 \\
10, * * p<0.05 \text {, }\end{array}$ & $\begin{array}{l}\text { ent and } 93 \\
\text { of post-int } \\
\text { ine intake } i \\
g \text { with date } \\
<0.01 \text {. }\end{array}$ & $\begin{array}{l}\text { tion arrests. } \\
\text { ew. Pre- } \\
\text { domized job }\end{array}$ \\
\hline
\end{tabular}


Appendix Table 1: Analysis of Non-followed

Intensive Job Assistance

Age

Married

Hispanic

Other Race

Disability

High School/GED Ed

Drug/Alcohol Treatment

Vocational Training

Educational Training

Job Training

Life Skills

Religious Studies

Prisoner Assistance

Other Self Help

Ethnic Organization

Pre-Release Program

Community Acts

Arts \& Crafts

Paid Work

Prior Job Training

Constant

F-test

p-value of F-test

$N$

Notes: Authors' analysis of 256 initial participants in the America Works

the outcome of interest is whether arrest records could be matched to the provided individual identifiers. Fully 219

participants could be matched with arrest records and were included in the subsequent analysis. Individual characteristics are from the baseline intake interview. $* \mathrm{p}<0.05$, $* * \mathrm{p}<0.01$.
(1)

(2)

$-0.000$

$(0.043)$

0.005

(0.003)

0.101

$(0.057)$

$-0.000$

$(0.100)$

$-0.049$

$(0.079)$

$-0.080$

(0.088)

0.079

(0.065)

0.051

(0.096)

(3)

0.008

(0.044)

0.005

(0.003)

0.135

(0.071)

$-0.011$

(0.093)

$-0.032$

(0.071)

$-0.067$

(0.086)

0.076

(0.069)

0.046

(0.098)

0.056

$(0.068)$

0.010

(0.055)

0.085

(0.066)

$-0.078$

(0.065)

$-0.045$

(0.050)

0.102

(0.064)

$-0.014$

$(0.065)$

$-0.088$

(0.076)

$-0.078$

(0.064)

0.052

(0.062)

$-0.047$

(0.074)

0.019

(0.048)

0.051

(0.045)

$0.852 * *$

(0.032)

0.03

$0.587 * *$

$0.550 * *$

(0.152)

$0.139)$

0.98

0.49

0.49

256 


\begin{tabular}{|c|c|c|c|c|c|c|c|c|}
\hline \multicolumn{9}{|c|}{$\begin{array}{c}\text { Appendix Table 2 } \\
\text { Summary of Unit Crime Cost Estimates Reported in Literature (2008 dollars) }\end{array}$} \\
\hline Type of Crime & $\begin{array}{c}(1) \\
\text { Aos et al. } \\
(2001)\end{array}$ & $\begin{array}{l}(2) \\
\text { Cohen } \\
(1988)\end{array}$ & $\begin{array}{l}(3) \\
\text { Cohen et al. } \\
(2004)\end{array}$ & $\begin{array}{c}(4) \\
\text { Cohen \& } \\
\text { Piquero } \\
(2009)\end{array}$ & $\begin{array}{c}(5) \\
\text { Miller et } \\
\text { al. } \\
(1993)\end{array}$ & $\begin{array}{c}\text { (6) } \\
\text { Miller et } \\
\text { al. } \\
(1996)\end{array}$ & $\begin{array}{c}(7) \\
\text { Rajkumar } \\
\text { \& French } \\
\text { (1997) }\end{array}$ & $\begin{array}{c}(8) \\
\text { McCollister et al. } \\
(2010)\end{array}$ \\
\hline Murder & $4,423,614$ & & $11,350,687$ & $\begin{array}{l}4.6-5 \\
\text { million }\end{array}$ & $4,144,677$ & $4,380,559$ & & $8,982,907$ \\
\hline Rape/Sexual assault & 369,739 & 97,962 & 286,277 & 290,000 & 80,403 & 124,419 & & 240,776 \\
\hline Aggravated assault & 105,545 & 23,025 & 84,555 & 85,000 & $24,987.00$ & 21,451 & 76,829 & 107,020 \\
\hline Armed robbery & & & & 280,000 & & & & \\
\hline Robbery & 219,286 & 24,168 & 280,237 & 39,000 & 33,036 & 18,591 & 33,143 & 42,310 \\
\hline Arson & & & & 115,000 & 41,900 & 53,629 & & 21,103 \\
\hline Larceny/Theft & & 344 & & 4,000 & & 529 & 1,104 & 3,532 \\
\hline Motor vehicle theft & & 6,006 & & 17,000 & & 5,720 & 1,723 & 10,772 \\
\hline Household & & 2,575 & 30,197 & & & 2,145 & 1,974 & 6,462 \\
\hline $\begin{array}{l}\text { Drunk-driving } \\
\text { crash }\end{array}$ & & & & 60,000 & & & & \\
\hline Burglary & & & 25,000 & 35,000 & & & & \\
\hline Embezzlement & & & & & & & & 5,480 \\
\hline Fraud & & & & 5,500 & & & & 5,032 \\
\hline Stolen property & 22,739 & & & & & & 151 & 7,974 \\
\hline $\begin{array}{l}\text { Forgery and } \\
\text { counterfeiting }\end{array}$ & & & & & & & 833 & 5,265 \\
\hline Vandalism & & & & 2,000 & & & & 4,860 \\
\hline $\begin{array}{l}\text { Prostitution, false } \\
\text { statements, etc. }\end{array}$ & & & & 500 & & & & \\
\hline \multicolumn{9}{|c|}{$\begin{array}{l}\text { Note: Unit cost values inflated using Bureau of Labor Statistics inflation calculator based on consumer price index (CPI). U.S. Department of } \\
\text { Labor 2008; see http://www.bls.gov/data/inflation_calculator.htm. } \\
\text { (1) Estimates combine Washington State and local governmental operating costs paid by taxpayers (originally reported in } 2000 \text { dollars) and } \\
\text { costs incurred by crime victims from Miller et al. } 1996 \text { (reported in } 1995 \text { dollars). Values reflect present value cost of each offense used to } \\
\text { calculate the benefits of adult community-based substance-abuse treatment. Cost per assault is for aggravated assault. } \\
\text { (2) Original estimates in } 1985 \text { dollars. Jury compensation approach to estimate monetary value for pain, suffering, and fear in personal injury } \\
\text { cases. } \\
\text { (3) Original crime cost estimates in } 2000 \text { dollars. Estimated using contingent valuation method (willingness to pay). } \\
\text { (4) Additional estimates to (2) by including (3). } \\
\text { (5) Original estimates in } 1989 \text { dollars. Victim costs of violent crime and resulting injuries. } \\
\text { (6) Original estimates in } 1993 \text { dollars. Estimates reflect victim losses including medical and mental health-care spending, tangible losses, and } \\
\text { reduced quality of life. Excludes adjudication and sanctioning. } \\
\text { (7) Original crime cost estimates reported in } 1992 \text { dollars. Estimated using combination of cost of illness and jury compensation approaches. } \\
\text { Cost of assault is for aggravated assault. }\end{array}$} \\
\hline
\end{tabular}

